\title{
Sub- and supercritical water in the processes of conversion of Domanik rock organic matter
}

\author{
Z.R. Nasyrova ${ }^{1}$, G.P. Kayukova ${ }^{2}$, A.E. Chemodanov ${ }^{1}$, A.V. Vakhin ${ }^{1}$ \\ ${ }^{1}$ Institute of Geology and Oil and Gas Technologies, Kazan Federal University, Kazan, Russia \\ ${ }^{2}$ Arbuzov Institute of Organic and Physical Chemistry, FRC Kazan Scientific Center, Russian \\ Academy of Science, Kazan, Russia
}

\begin{abstract}
Studies on the conversion of organic matter of high-carbon Domanik (siliceous-clay carbonate) rock of the Romashkinskoye deposit with a mineral content $\mathrm{C}_{\text {org }}$ of $7.07 \%$ in sub- and supercritical water have been carried out. It was shown that subcritical water at a temperature of $320^{\circ} \mathrm{C}$ and $17.0 \mathrm{MPa}$ leads to a partial decomposition of the kerogenic structure, increasing the yield of bitumen from 3.12 to $3.98 \%$, and a more complete recovery of asphaltenes and heavy $\mathrm{C}_{22}-\mathrm{C}_{30}$ n-alkanes from the rock sample. Supercritical water at temperatures of 374 and $420^{\circ} \mathrm{C}$ and pressures above $24.4 \mathrm{MPa}$ leads to intensive formation of hydrocarbon and inorganic gases in the processes of kerogen decomposition, destruction of aliphatic substituents from condensed heteroatomic structures of resins and asphaltenes, and the carbonate component of Domanik rock. Degradation of the organic matter of the Domanik rock is also accompanied by the formation of saturated hydrocarbons with an increased content of light $\mathrm{C}_{12^{-}}$ $\mathrm{C}_{21}$ n-alkanes, and carbonaceous substances, such as carbene-carboids. Changes in the structure of asphaltenes and their paramagnetic properties were determined by the EPR method. The influence of sub- and supercritical water on phase changes in the composition of rock minerals, as well as on the yield and composition of formed gases, was revealed.
\end{abstract}

\section{INTRODUCTION}

Shale strata in Russia are represented by accumulations of bituminous rocks of the Bazhenov Formation of Western Siberia and Domanik deposits of the Volga-Ural oil and gas province $[1,2,3]$. These low-permeability dense rocks form the main oil source strata, in which highly depleted hydrocarbon deposits occur where they are formed. In the territory of the Republic of Tatarstan, the Domanik strata are represented by highcarbonaceous carbonate-siliceous rocks with limestones and dolomites, containing sapropelic dispersed organic matter (OM) of up to $20 \%$ [4]. The OM composition of oil source strata is characterized by a high content of tarry asphaltene substances and kerogen, which is a natural geopolymer with an irregular structure and is considered in many studies as a source of generation of oil hydrocarbons $[5,6,7]$.

At present, in many oil and gas-bearing territories, a spatial relationship between the location of oil and gas fields and the permeable zones of the earth's crust — deep faults and fractures has been established $[8,9]$. The formation of Domanik deposits with a high OM 
content is also associated with the occurrence of tectonic and volcanic processes in the Volga-Ural region, which contributed to the accumulation of huge strata of organic matter in depressions and hollows and the penetration of hydrothermal fluids and deep heat into the sedimentary layers. The main components of deep fluids are carbon dioxide, methane, water, and hydrogen. At high reservoir pressures and temperatures, methane, carbon dioxide, and water can become supercritical and exhibit increased chemical activity in the processes of OM conversion [5]. It was shown in [10, 12, 13] that water under supercritical conditions at temperatures above $374.3^{\circ} \mathrm{C}$ and pressures above $22.1 \mathrm{MPa}$ can penetrate the structure of kerogen and break its structural skeleton, leading to the formation of bituminous substances. This gives reason to believe that the development of Domanik sedimentary rocks can be carried out using supercritical fluids, in particular, supercritical water. This sphere is important and relevant not only from the point of view of studying the processes of oil formation but also in terms of developing technologies for the development of Domanik strata.

The purpose of the work is to study the processes of OM decomposition of high-carbon Domanik rocks in sub- and supercritical water environment.

\section{Methods and methodology}

\subsection{Object of study}

The object of the study was a sample of siliceous-clay carbonate rock from the deposits of the Domanik horizon of the Chishminskaya area of the Romashkinskoye deposit (Fig. 1). In terms of explored oil reserves, the Romashkinskoye deposit is one of the largest fields in the world with reserves of more than 5 billion tons [14]. This deposit is unique not only in its size and reserves but extremely interesting in geological terms. The field is located in the arched part of the South Tatar Arch - one of the major structural elements of the Volga-Ural oil and gas province. Oil deposits occur near the crystalline basement. There is an assumption about the deep origin of oil, about the "feeding" the hydrocarbon inflow from the foundation rocks [15]. This assumption confirms the presence of the so-called "abnormal" wells with unusual properties at the Romashkinskoye deposit that contradicts the "law of declining production" [16]. Researchers in their works [17, 18, 19]; associate the flow of abiogenic oil from the depths to the sedimentary sequence through faults or weakened zones in the crystalline basement.

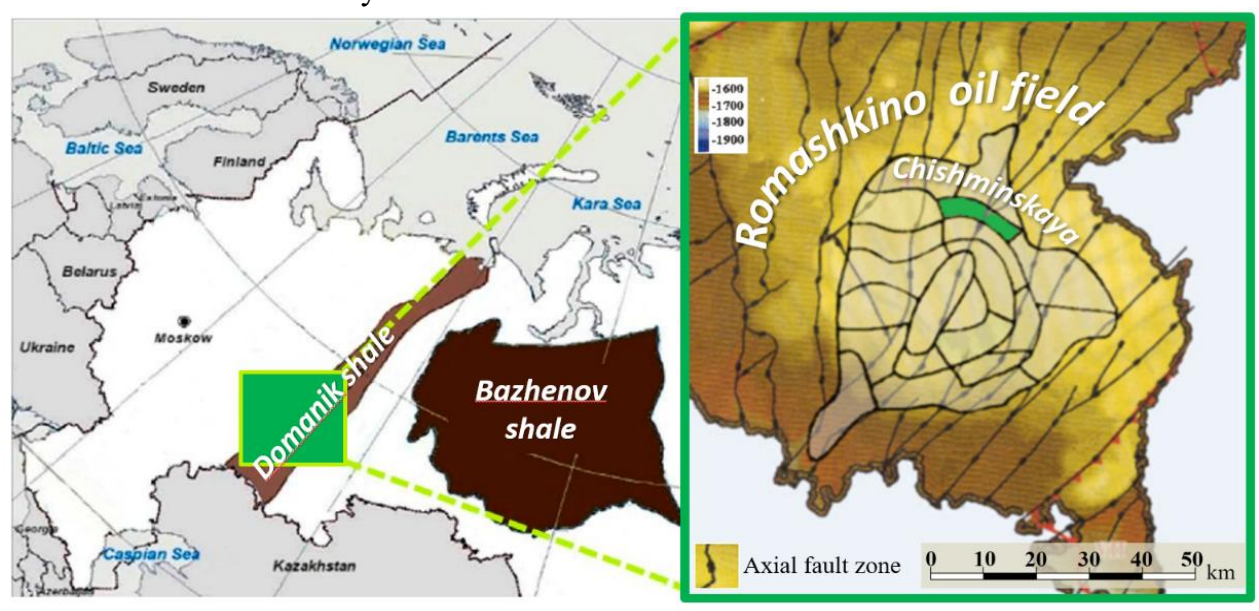

Fig. 1. The location scheme of the Chishminskaya area in the Romashkinsoye deposit. 
In addition to possible deep hydrocarbon sources, Domanik oil source strata are widespread in this field in the sediments of the Semilukian, Mendymian, and Sargaevskian horizons of the Upper Devonian of the Frasnian formations, which are analogous to shale strata in the United States $[1,2,12]$. PJSC TATNEFT is conducting intensive research in many areas of the Romashkinskoye deposit to study these strata in terms of shale oil production. One of such promising objects is the Chishminskaya area, located in the north of the Romashkinskoye deposit (Figure 1). The industrial oil-bearing objects of the area are the D0 beds of the Kynovian horizon and the DI (a, b1, b2, b3, c, d, e) strata of the Pashian horizon of the Lower Frasnian Upper Devonian sub-tier. According to its physicochemical properties, the Chishminskaya oil region belongs to the group of low-sulfurous and paraffinic. Prospective zones include carbonate-siliceous deposits of Upper Devonian D3 Domanik type with OM content over $0.5 \%$ and maturity degree $\mathrm{R} 0=0.9$, which are widely spread in the Romashkinskoye deposit from the Frasnian layer of Upper Devonian (D3dm) to Famennian layer (D3fm). At present, theDomanik deposits are little studied, since most of the formed hydrocarbons remain in the matrix forming the oil source stratum. Besides, deposits of the Domanik type are highly differentiated not only in the section but also in the area.

A sample of Domanik rock taken from a depth of $1,720 \mathrm{~m}$ of the SemilukianMendymian horizon is characterized by the following mineral composition: $43 \%$ quartz, $19 \%$ calcite, $19 \%$ microcline, $12 \%$ mica, and $6 \%$ dolomite [20]. According to the RockEval pyrolytic method, the content of organic carbon $\left(\mathrm{C}_{\text {org }}\right)$ in the rock is $7.07 \%$. The content of free hydrocarbons in the rock is extremely low $\left(\mathrm{S}_{1}=1.52 \mathrm{mg} / \mathrm{g}\right)$, the main part of $\mathrm{OM}$ is insoluble kerogen $\left(\mathrm{S}_{2}=22.52 \mathrm{mg} / \mathrm{g}\right)$.

\subsection{Autoclave experiments}

Autoclave experiments were carried out in a Parr Instruments reactor for 60 minutes in a neutral environment. For each experiment, a $100 \mathrm{~g}$ sample of ground rock was loaded into the autoclave. In the first two experiments, $130 \mathrm{ml}$ of water was added. To prevent a sharp increase in the pressure of the gas-vapor mixture, the amount of water in the third experiment was reduced to $50 \mathrm{ml}$ and was $50 \%$ by weight of dry rock [21]. The initial pressure of nitrogen in the system was $1 \mathrm{MPa}$. During autoclave experiments, the system pressure was increased to $17 \mathrm{MPa}$ at $320^{\circ} \mathrm{C}$, to $24.6 \mathrm{MPa}$ at $374^{\circ} \mathrm{C}$, and to 24.4 at $420^{\circ} \mathrm{C}$ (Table 1).

Table 1. Conditions for autoclave experiments

\begin{tabular}{ccccccc}
\hline № & $\begin{array}{c}\text { The } \\
\text { amount of } \\
\text { rock, } \mathrm{g}\end{array}$ & $\begin{array}{c}\text { The } \\
\text { amount of } \\
\text { water, } \mathrm{g}\end{array}$ & $\begin{array}{c}\text { Temperat } \\
\text { ure, }{ }^{\circ} \mathrm{C}\end{array}$ & $\begin{array}{c}\text { Pressur } \\
\mathrm{e}, \mathrm{MPa}\end{array}$ & $\begin{array}{c}\text { The } \\
\text { density of } \\
\text { water, } \\
\mathrm{g} / \mathrm{cm} 3\end{array}$ & $\begin{array}{c}\text { Water } \\
\text { condition }\end{array}$ \\
\hline 1 & 100 & 130 & 320 & 17.0 & 0.322 & Subcritical \\
\hline 2 & 100 & 130 & 374 & 24.6 & 0.322 & Supercritical \\
\hline 3 & 100 & 50 & 420 & 24.4 & 0.118 & Supercritical \\
\hline
\end{tabular}

\subsection{Analysis of samples before and after autoclave experiments}

Samples before and after autoclave experiments were studied using physicochemical methods of analysis: X-ray structural spectroscopy of rocks, gas chromatography of gases, pyrolytic Rock-Eval method for rocks, SARA analysis of bitumens, and electronic paramagnetic resonance examination of asphaltenes. 


\section{Discussions}

\subsection{Mineral composition of rock samples}

The method of X-ray diffraction analysisrevealed structural and phase changes in the mineral composition of Domanik rock; in particular, the experiments with supercritical water recorded transformations in the structure of mica due to the isolation of a separate phase of montmorillonite from it (Figure 2). It should be noted that the transition of mica into a mixed layer of montmorillonite mica is is an intermediate form in the transformation of mica into kaolinite [22]. The presence of clayey rock-forming minerals with catalytic properties in the hydrothermal system of water in the sub- and supercritical state can also have a significant effect on the organic matter transformation of these rocks.

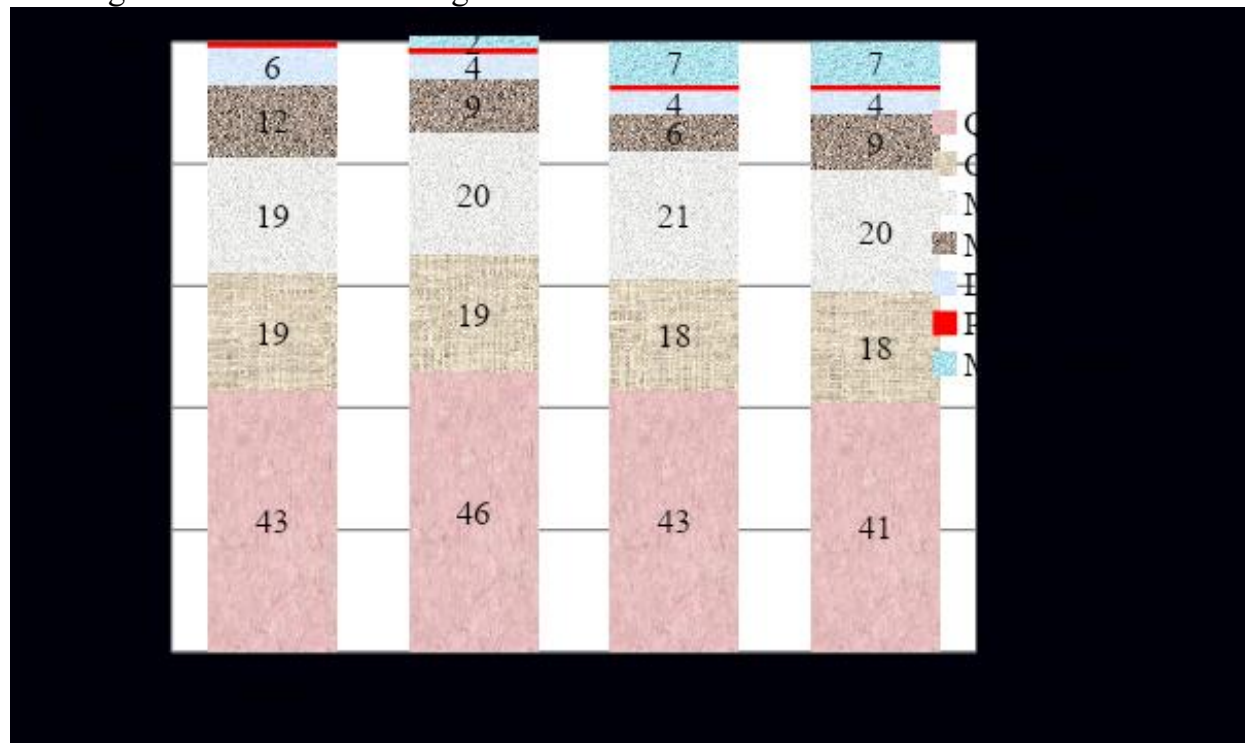

Fig. 2. The mineral composition of rock samples before and after autoclave experiments.

\subsection{The composition of gases formed during autoclave experiments}

After completion of each experiment, the composition of formed gases was analyzed (Figure 3). The most intensive formation of gased corresponds to the experiment with supercritical water at temperature of $420^{\circ} \mathrm{C}$ and a pressure of $24.4 \mathrm{MPa}$. The formation of hydrocarbon gases of the series $\mathrm{CH}_{4}, \mathrm{C}_{2} \mathrm{H}_{6}, \mathrm{C}_{3} \mathrm{H}_{8}, \mathrm{i}-\mathrm{C}_{4} \mathrm{H}_{10}$, etc. indicates the occurrence of destructive processes by the radical chain mechanism. The processes of destruction of the $\mathrm{C}-\mathrm{H}$ and $\mathrm{C}-\mathrm{O}$ bonds are marked by the presence of $\mathrm{H}_{2}$ and $\mathrm{O}_{2}$. The high content of $\mathrm{CO}_{2}$ in the composition of the formed gases may be due to the destruction of both the organic part and carbonate minerals of rocks during experiments in sub- and supercritical water. It should be notedthat the formation of gases contributes to more intensive oil recovery from sedimentary rocks. 


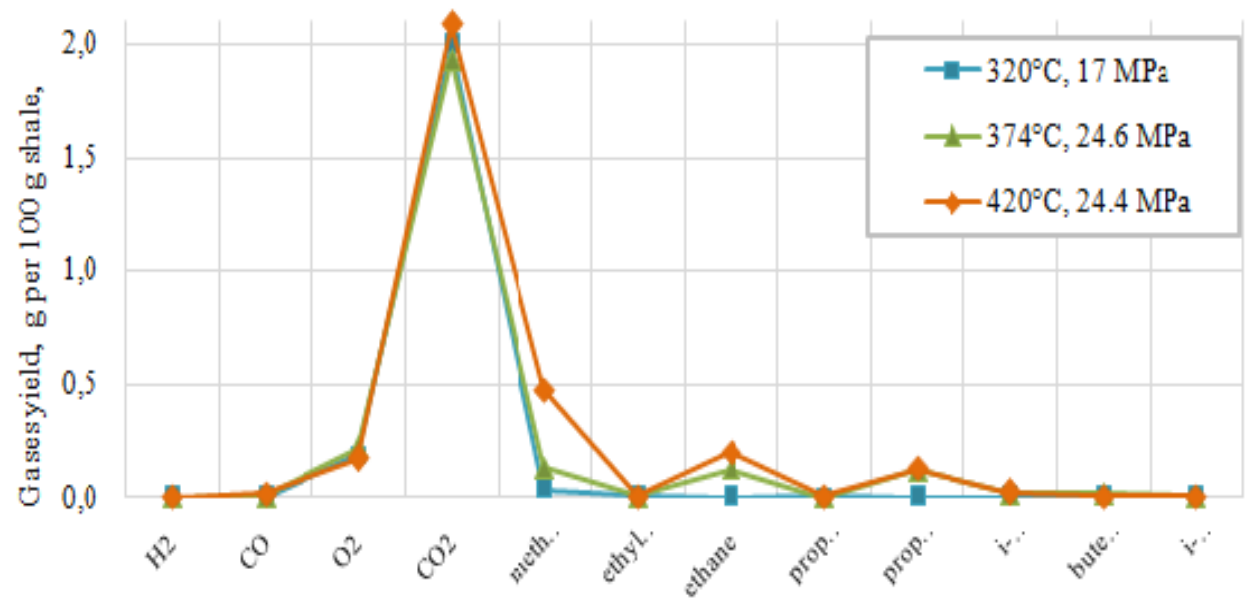

Fig. 3. Composition of gases generated during autoclave experiments

\subsection{Rock characterization by Rock-Eval pyrolytic method}

The amount of free hydrocarbons and kerogen in rock samples before and after autoclave experiments is shown in Figure 4a. According to the Rock-Eval pyrolytic analysis, the original sample of Domanik rock with a $\mathrm{C}_{\text {org }}$ content of $7.07 \%$ belongs to the class of very good source rocks and is characterized by a fairly high oil formation potential $\left(\mathrm{S}_{1}+\mathrm{S}_{2}\right)=$ $23.69 \mathrm{HC} / \mathrm{g}$ of rock. Exposure of the rock tosupercritical water leads to an intensive decomposition of the kerogen structure, similar to the natural catagenesis process. This is evidenced by a sharp decrease in the content of hydrocarbons formed from kerogen $\left(\mathrm{S}_{2}\right)$ from 37.17 to $1.95 \mathrm{mg} / \mathrm{g}$ of rock at $374^{\circ} \mathrm{C}$, as well as a decrease in the $\mathrm{C}_{\text {org }}$ value from 7.07 to $3.12 \%$.
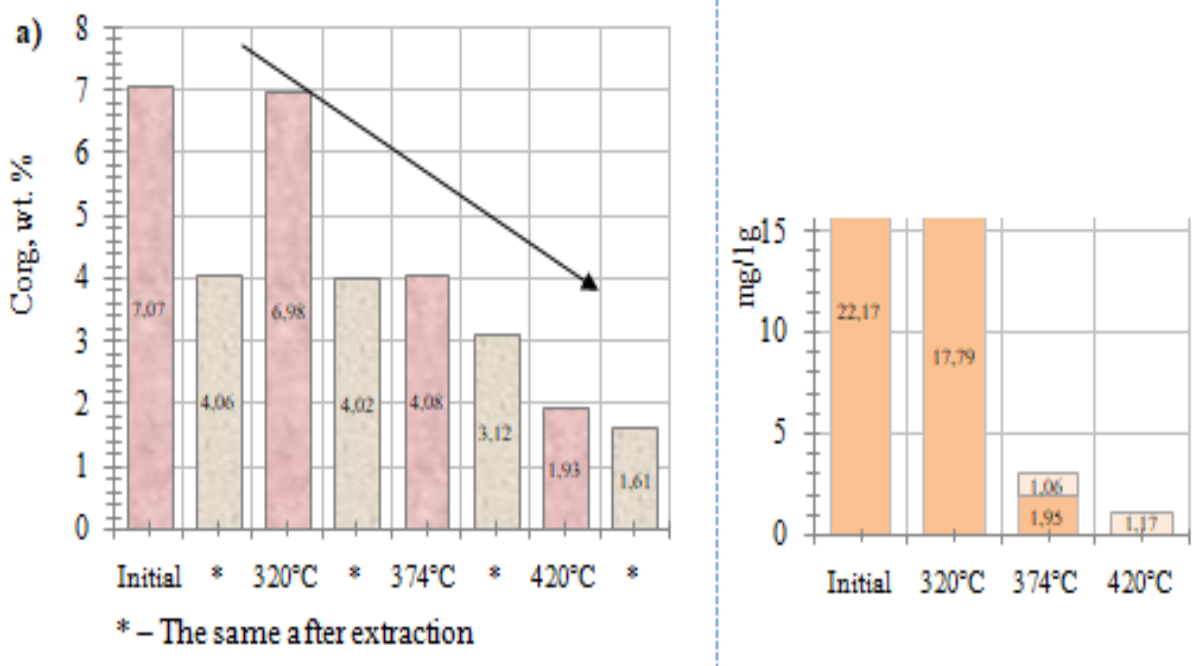

Fig. 4. The results of the pyrolytic analysis of Rock-Eval rock samples before and after autoclave experiments: a) $\mathrm{C}_{\text {org }}$ content; b) the content of formed hydrocarbons when heating rock samples to a temperature of $300^{\circ} \mathrm{C}\left(\mathrm{S}_{1}\right)$ and from 300 to $600^{\circ} \mathrm{C}\left(\mathrm{S}_{2}\right)$ 


\subsection{Composition of bitumens before and after autoclave experiments}

Decomposition of kerogen is reflected in the results of the group composition of bitumen extracted from rock samples by organic solvents [23] after experiments at different temperatures (Table 2). The initial bitumen contains $29.0 \%$ of asphaltenes, $37.0 \%$ of resins, $14.8 \%$ of saturated, and $19.2 \%$ of aromatic hydrocarbons. Subcritical water affects the extraction of sorbed asphaltenes from the rock, as indicated by the increase in their content to $32.91 \%$. As a result, the output of the bitoid is also increased from 3.12 to $3.98 \%$. Supercritical water exposure to the rock at $374^{\circ} \mathrm{C}$ and $24.6 \mathrm{MPa}$ results in decomposition of resins and asphaltenes and the formation of low-boiling saturated hydrocarbons in the amount of $33.9 \%$. At that, insoluble carbonaceous substances are formed, such as carbenecarboids in the amount of $14.49 \%$. The formation of such substances can result from both the destruction of the asphaltene alkyl chains and the decomposition of the kerogenic structure $[27,28,29]$. With an increase in the temperature of supercritical water to $420^{\circ} \mathrm{C}$, the yield of bitumen from the rock sharply decreases to $0.91 \%$, as well as its content of carbene-carboids to $2.03 \%$.

Table 2. Group composition of rock extracts before and after autoclave experiments

\begin{tabular}{|c|c|c|c|c|c|c|}
\hline \multirow{2}{*}{$\begin{array}{l}\text { Object, } \\
\text { experimental } \\
\text { conditions }\end{array}$} & \multirow{2}{*}{$\begin{array}{r}\text { Bitum } \\
\text { en output } \\
(\% \\
\text { wt. })\end{array}$} & \multicolumn{5}{|c|}{ Group composition (\% wt.) } \\
\hline & & $\begin{array}{l}\text { Saturat } \\
\text { ed }\end{array}$ & $\begin{array}{l}\text { Arom } \\
\text { atic }\end{array}$ & $\begin{array}{l}\text { Resin } \\
\mathrm{s}\end{array}$ & $\begin{array}{l}\text { Asphalte } \\
\text { nes }\end{array}$ & $\begin{array}{r}\text { Carbene } \\
\text { - Carboids }\end{array}$ \\
\hline Source sample & 3.12 & 14.81 & 19.17 & 37.00 & 29.02 & - \\
\hline $320^{\circ} \mathrm{C}, 17 \mathrm{MPa}$ & 3.98 & 16.89 & 22.70 & 27.46 & $32 ., 91$ & - \\
\hline $\begin{array}{ll} & 374^{\circ} \mathrm{C}, \\
\mathrm{MPa}\end{array}$ & 3.08 & 33.91 & 14.33 & 13.49 & 23.77 & 14.49 \\
\hline $\begin{array}{l}420^{\circ} \mathrm{C}, 24.4 \\
\mathrm{MPa}\end{array}$ & 0.91 & 36.16 & 32.56 & 21.92 & 7.34 & 2.03 \\
\hline
\end{tabular}

\subsection{Characterization of asphaltenes by electron paramagnetic resonance (EPR)}

Figure 5 shows the EPR spectra of asphaltene samples before and after autoclave experiments. The observed decrease in the content of free radicals in the composition of asphaltenes with increasing experimental temperature indicates the separation of alkyl substituents and subsequent carbonization processes 

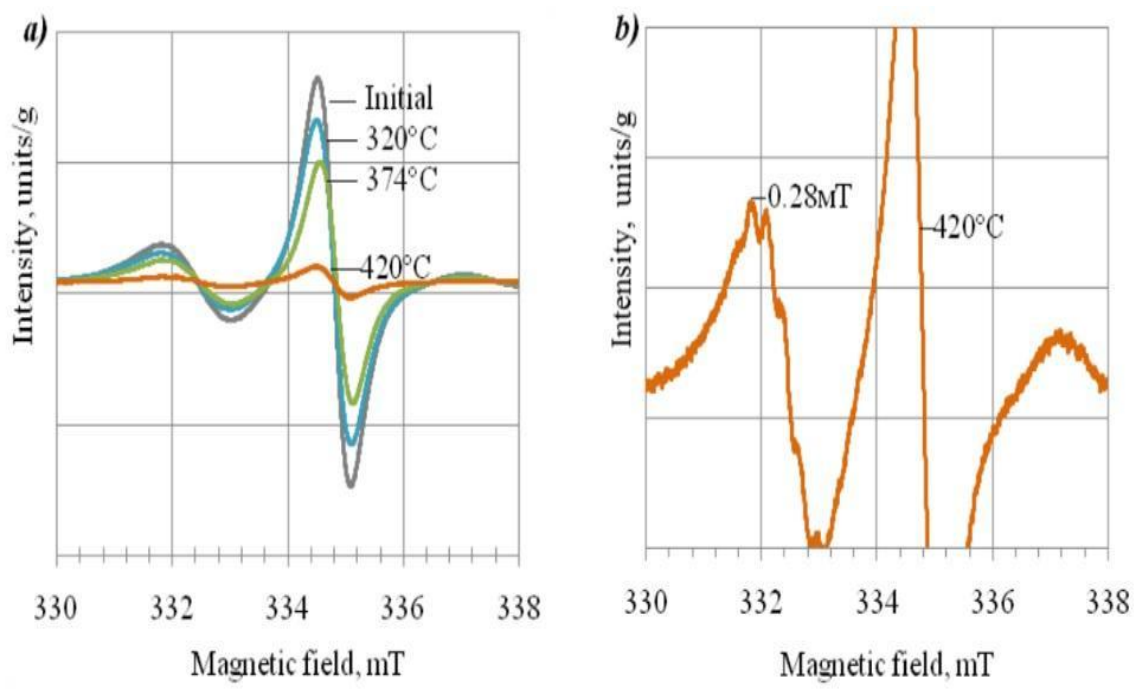

Fig. 5. Data on the EPR parameters of asphaltene samples before and after autoclave experiments.

It is important to note a feature of the EPR spectrum of asphaltenes after the experiment in supercritical water at $420^{\circ} \mathrm{C}$ associated with the appearance on the vanadyl line of a super-ultrafine cleavage spectrum from ${ }^{14} \mathrm{~N}$ nitrogen nuclei (Figure $5 \mathrm{~b}$ ). The number of observed lines and the distance between them $(0.28 \mathrm{mT})$ corresponds to the ultrafine spectrum of four equivalent ${ }^{14} \mathrm{~N}$ nitrogen atoms $(I=1)$, presented in $[29,30]$. This spectral peculiarity indicates the presence of a vanadyl ion in the porphyrin ring of monocycloalkylporphyrins having a mass 2 units less than that of alkyl porphyrins. Appearance of new vanadylporphyrin structures in asphaltenes after experiment in supercritical water at $420^{\circ} \mathrm{C}$ indicates probable conversion of alkylporphyrins to monocycloalkylporphyrins as a result of dealkylation, demetallization, and hydrogenation processes.

\section{Conclusions}

Studies on the OM conversion of the Romashkinskoye Domanikdeposit in sub- and supercritical water environment led to the following conclusions.

1. Subcritical water at $320^{\circ} \mathrm{C}$ and $17.0 \mathrm{MPa}$ leads to an increase in the yield of bitumen from 3.12 to $3.98 \%$ as a result of more complete extraction of asphaltenes and heavy $\mathrm{C}_{22}-$ $\mathrm{C}_{30}$ n-alkanes from the rock.

2. Supercritical water at temperatures of 374 and $420^{\circ} \mathrm{C}$ and pressures above $24.4 \mathrm{MPa}$ lead to the intensive formation of hydrocarbon and inorganic gases in the decomposition of asphaltenes and kerogen, as well as rock minerals. Changes in the mineral composition of the rocks occurred with mica as a result of the isolation of a separate phase of montmorillonite from it. The decomposition of organic matter occurs by the detachment of aliphatic chains from condensed structures with the formation of light $\mathrm{C}_{12}-\mathrm{C}_{21}$ n-alkanes and carbonaceous substances, such as carbene-carboids. This is confirmed by a decrease in the content of free radicals in the composition of asphaltenes with increasing experimental temperature. Supercritical water at $420^{\circ} \mathrm{C}$ leads to changes in the structure of vanadyl porphyrins that are part of asphaltenes: alkyl porphyrins as a result of processes of dealkylation, demetallization, and hydrogenation are converted to monocycloalkyl porphyrins. 
The reported study was funded by RFBR, project number № 20-35-90112.

\section{Reference}

1. Kayukova, G. P., Mikhailova, A. N., Khasanova, N. M., Morozov, V. P., Vakhin, A. V., Nazimov, N. A., Sotnikov, O. S \& Khisamov, R. S. Geofluids Influence of Hydrothermal and Pyrolysis Processes on the Transformation of Organic Matter of Dense Low-Permeability Rocks from Domanic Formations of the Romashkino Oil Field, (2018).

2. Khisamov, R. S., Bazarevskaya, V. G., Tarasova, T. I., Mikhailova, O. V., \& Mikhailov, S. N. Oil industry Geochemical evidence for petroleum potential of Domanic deposits in the Republic of Tatarstan 98, 10-13 (2016).

3. Khisamov, R. S., Bazarevskaya, V. G., Panina, S. A., Abusalimova, R. R., Abdrashitova, A. F., \& Grishanina, O. A. Oil Industry Journal Assessment of reproducibility of estimate parameters based on core studies and well logging data for heavy oil reservoirs 6, 18-21 (2017).

4. Khisamov, R. S., Zakirov, I. S., Zakharova, E. F., Bazarevskaya, V. G., Abusalimova, R. R., \& Timirov, D. A. Oil Industry Experience of studying and development of domanic deposits on the example of bavlinskoye field of the republic of Tatarstan 11, 78-83 (2018).

5. Tissot, B., Durand, B., Espitalie, J., \& Combaz, A. AAPG bulletin Influence of nature and diagenesis of organic matter in formation of petroleum 58(3), 499-506 (1974).

6. Behar, F., Lorant, F. and Lewan, M. Organic Geochemistry Role of NSO compounds during primary cracking of a Type II kerogen and a Type III lignite' 39(1), 1-22 (2008).

7. Guan, X. H., Liu, Y., Wang, D., Wang, Q., Chi, M. S., Liu, S., \& Liu, C. G. Energy \& Fuels Three-dimensional structure of a huadian oil shale kerogen model: An experimental and theoretical study 29(7), 4122-4136 (2015).

8. Gottikh, R.P., \&Pisotskiy, B.I. Genezis nefti i gaza $O$ glubinnosti nefteobrazuyushchikh flyuidov 90-92 (2003).

9. Lifshits, S. K. Herald of the Russian Academy of Sciences The principle of oil formation in the supercritical flow of deep fluids 79(2), 174-178 (2009).

10. Kruse, A. \& Dinjus, E. The Journal of supercritical fluids Hot compressed water as reaction medium and reactant: properties and synthesis reactions 39(3), 362-380 (2007).

11. Brunner, G. The Journal of Supercritical Fluids Near critical and supercritical water. Part I. Hydrolytic and hydrothermal processes' 47(3), 373-381 (2009).

12. Anan'yev, V. V., Smelkov, V. M. \& Pronin, N. V. Geologiya nefti i gaza Prognoznaya otsenka resursnoy bazy mendym-Domanikovykh otlozheniy kak os-novnogo istochnika uglevodorodnogo syr'ya tsentral'nykh rayonov Volgo-Ural'skoy neftegazonosnoy provintsii 1 (2007).

13. Savel'ev, V. V., Pevneva, G. S., Surkov, V. G., \& Golovko, A. K. Solid Fuel Chemistry Effects of mechanical treatment and water under supercritical conditions on oil-Saturated sandstone 45(2), 135-141 (2011).

14. Galimov, E. M. \& Kamaleeva, A. I. Geochemistry The hydrocarbon source of the super-giant oil Romashkinskoye field (Tatarstan) is an inflow from a crystalline basement or oil source sedimentary deposits 2, 103 (2015). 
15. Galimov, E. M. \& Kamaleyeva, A. I. Geokhimiya Istochnik Uglevodorodov Supergigantskogo Neftyanogo Mestorozhdeniya Romash-kino (Tatarstan) - Pritok Iz Kristallicheskogo Fundamenta Ili Neftematerinskiye Osa-dochnyye Otlozheniya 2 , 103-122 (2015).

16. Muslimov, R.K. Glumov, I.F., Plotnikova, I.N., Trofimov, V.A., \& Nurgaliyev, D.K. Geologiya nefti i gaza Neftyanyye $i$ gazovyye mestorozhdeniya samorazvivayushchiyesya i postoyanno vozobnovlyayemyye ob"yekty' 1, 43-49 (2004).

17. Muslimov, R. K. Georesursy New geological ideas are the basis of the progressive development of hydrocarbons mineral resource base in the old oil-producing regions of Russia in the XXI century 5 (47), 3-6 (2012).

18. Plotnikova, I. N. Geologo-geofizicheskiye i geokhimicheskiye predposylki perspektiv neftegazonosnosti kristallicheskogo fundamenta Tatarstana 171 (2004).

19. Trofimov, V. A., Korolev, E. A. \& Khuzin, I. A. Materialy Vseross. konf. s mezhdunarod. uchast. «Degazatsiya Zemli: Geotektonika, geodinamika, geoflyuidy, neft' i gaz, uglevodorody i zhizn' Chto takoye neftepodvodyashchiye kanaly, 577-579 (2010).

20. Nasyrova, Z. R., Kayukova, G. P., Onishchenko, Y. V., Morozov, V. P., \& Vakhin, A. V. Energy \& Fuels Conversion of high-carbon Domanic Shale in sub-and supercritical water 34(2), 1329-1336 (2020).

21. Nasyrova, Z. R., Kayukova, G. P., Khasanova, N. M., \& Vakhin, A. V. Petroleum Chemistry Transformation of organic matter of domanik rock from the Romashkino oilfield in sub-and supercritical water 60(6), 683-692 (2020).

22. Stoch, L. \& Sikora, W. Clays and Clay Minerals Transformations of micas in the process of kaolinitization of granites and gneisses 24(4), 156-162 (1976).

23. Chemodanov, A. E., Akhmadullin, R. R., Sudakov, V. A., Usmanov, S. A., Khayrtdinov, R. K. Petroleum Science and Technology Geochemical modeling with the use of vertical and horizontal relative concentrations of oil compounds for the heavy oil fields 36(14), 1100-1106 (2018).

24. Kayukova, G. P., Kiyamova, A. M., Mikhailova, A. N., Kosachev, I. P., Petrov, S. M., Romanov, G. V., Sitdikova, L.M., Plotnikova, I.N. \& Vakhin, A. V. Chemistry and Technology of Fuels and Oils Generation of hydrocarbons by hydrothermal transformation of organic matter of Domanik rocks 52(2), 149-161 (2016).

25. Kayukova, G. P., Mikhailova, A. N., Kosachev, I. P., Eskin, A. A., \& Morozov, V. I. Petrochemistry The influence of natural minerals-pyrite and hematite on the conversion of organic matter of Domanic rock in hydrothermal processes 59(1), 28-38 (2019).

26. Kayukova, G. P., Mikhailov, A. N., Kosachev, I. P., Morozov, V. P., \& Vakhin, A. V. Petroleum Chemistry Hydrothermal Transformations of Organic Matter of CarbonRich Domanik Rock in Carbon Dioxide Environment at Different Temperatures 60, 278-290 (2020).

27. Antipenko, V.R., Bakanova, O.S. \& R.S. Kashapov. Bulletin of the Tomsk Polytechnic University. Geo Assets Engineering Characteristics of thermal stability of oils of natural bitumens and crude oils 330(5), 152-160 (2019).

28. Dmitriyevskiy, A.N., Valyayev, B.M., Rodkin, M.V. Degazatsiya Zemli i genezis uglevodorodnykh flyuidov $i$ mestorozhdeniy 370 (2002)

29. Gilinskaya, L. G. Zhurnal Strukturnoj Khimii EPR spectra of $V(I V)$ complexes and the structure of petroleum porphyrins 49(2), 259-268 (2008). 
30. Stoupakova, A., Fadeeva, N. P., Kalmykov, G. A., Bogomolov, A. K., Kiryukhina, T. A., Korobova, N., Shardanova, T.A, Suslova, A.A., Sautkin, R.S., Poludetkina, E.N. Geo-resources Search criteria for oil and gas in Domanik deposits of the Volga-Ural basin 61(2), 77-86 (2015). 